\title{
Effect of preputial washing on bacterial load and preservability of semen in Murrah buffalo bulls
}

\author{
G. S. Meena ${ }^{1}$, V. S. Raina², A. K. Gupta², T. K. Mohanty², M. Bhakat², M. Abdullah² and R. Bishist ${ }^{3}$
}

1. Krishi Vigyan Kendra, Bundi-323001, Rajasthan, India; 2. Artificial Breeding Research Centre, ICAR-National Dairy Research Institute, Karnal - 132 001, Haryana, India; 3. Dr. Yashwant Singh Parmar University of Horticulture \& Forestry, Nauni, Solan-173230, Himachal Pradesh, India.

Corresponding author: M. Bhakat, e-mail: bhakat.mukesh@gmail.com, GSM: ghanshyam774@gmail.com,VSR: vsrainandri@gmail.com, AKG: guptaak2009@gmail.com,

TKM: mohanty.tushar@gmail.com, MA: mabhatndri@gmail.com, RB: rohit.ndri@gmail.com

Received: 26-12-2015, Revised: 21-05-2015, Accepted: 29-05-2015, Published online: 28-06-2015

doi: 10.14202/vetworld.2015.798-803 How to cite this article: Meena GS, Raina VS, Gupta AK, Mohanty TK, Bhakat M, Abdullah M, Bishist R (2015) Effect of preputial washing on bacterial load and preservability of semen in Murrah buffalo bulls, Veterinary World 8(6): 798-803.

\begin{abstract}
Aim: To study the effect of preputial washing on bacterial load, preservability and semen quality in Murrah buffalo bulls

Materials and Methods: A total of 36 collections of three Murrah buffalo bulls maintained at Artificial Breeding Research Centre, ICAR-National Dairy Research Institute, Karnal, were collected at weekly intervals from each bull without preputial washing and latter ejaculates from same bull with preputial washing by infusing normal saline $(0.85 \%), \mathrm{KMnO}_{4}(0.02 \%)$ and savlon $(2.0 \%)$ to first, second and third bull, respectively. The microbial load and semen quality were evaluated during different hours of storage at refrigerated temperature $(0,24$ and $48 \mathrm{~h})$ and after thrawing of cryopreserved (at $\left.-196^{\circ} \mathrm{C}\right)$ semen.

Results: The results of preservation of semen at refrigerated temperature showed that bacterial load was markedly lower in ejaculates of bulls subjected to preputial washing. Semen preserved at refrigerator temperature and cryopreserved, the effect of washing solution was significant for individual motility (IM), non-eosiniphilic count, hypo-osmotic swelling reactivity (HOST), total plate count (TPC) and acrosome integrity. $\mathrm{KMnO}_{4}$ was found to be the best in lowering bacterial load, sperm abnormalities and in improving semen quality such as motility, non-eosinophilic count, HOST and acrosome integrity even up to $48 \mathrm{~h}$ of preservation and cryopreserved semen. Effect of duration of preservation and stage of cryopreservation was also significant for IM, non-eosiniphilic count, HOST, sperm abnormalities and acrosome integrity.
\end{abstract}

Conclusion: Overall the results suggested that preputial washing with $\mathrm{KMnO}_{4}$ solution improved the semen quality and reduced microbial load of Murrah buffalo bull's semen preserved at refrigerated temperature and cryopreservation.

Keywords: preputial washing, bacterial load, semen quality, preservability, Murrah buffalo bull.

\section{Introduction}

Production and dissemination of disease free quality semen are the major thrust of semen stations in India and throughout the world. Most of semen stations in India strictly follow minimum standard protocol for frozen semen production through diseases testing at regular interval to avoid the spread of the pathogen and widespread of ubiquitous bacteria by contaminated semen. The success of artificial insemination (AI) depends on the quality semen production and supply. One of the important factors, which influence semen quality [1] and further fertility [2] is a bacterial load in semen, therefore, considered in the quality control of semen [3]. In the breeding season, the sexual activity may lead to contamination of the penis and prepuce [4], which might increase microbial load in semen in natural mating condition. Higher microbial load in semen is a reflection of unhygienic management in various steps of bull management, semen collection, and processing [5]. To use semen for AI for

Copyright: The authors. This article is an open access article licensed under the terms of the Creative Commons Attributin License (http:// creative commons.org/licenses/by/2.0) which permits unrestricted use, distribution and reproduction in any medium, provided the work is properly cited. satisfactory conception [6], the bacterial load should not be more than $5000 \mathrm{Cfu} /$ dose.

Microbial contamination has effect on motility, morphology and various semen quality parameters [7] which may be due to direct effect or competition for nutrients [8] detected aerobic bacteria in almost all the collected semen samples but the various opportunistic pathogenic organisms in semen may cause reproductive disorders as well as may result in lower conception rate and increase in embryonic mortality, abortion and other complications in female. During bacterial isolation studies many types of bacteria have been found in frozen semen [9]. Bacterial contamination in frozen semen first leads to the production of macrophages and polymorphonuclear granulocytes and these cells generate reactive oxygen species that in turn impair sperm function and reduces its fertilization capability [10].

Many semen banks in India are getting microbial load estimated in frozen semen doses by either identified laboratory or from outside agencies or by themselves regularly [11]. Highly pathogenic bacteria like Tritrichomonas foetus inhabit the penis and prepuce of bull [12] as well as aerobic bacteria have 
been detected in almost all the semen samples collected from rams [13] and buffalo bulls [14], therefore though it is very difficult to achieve microbe free semen production but it can be minimized by routine preputial washing and hygienic bull management. Washing of preputial cavity prior to the collection of semen has therefore been advocated by many investigators to prevent microbial contamination. Very scanty information is available regarding impact of preputial washing on semen quality at refrigeration temperature and cryopreservation in Murrah buffalo besides the well-established fact of decrease in microbial load after preputial washing (APW) in crossbred and exotic bulls [15-17]. With an overall objective to augment quality germ plasm production in Murrah buffaloes, the present investigation was therefore carried out to study the effect of prepuce washing on semen quality including microbial quality aspects.

\section{Materials and Methods}

\section{Ethical approval}

We have carried out the experiment in accordance with the Guidelines laid down by the Institutional ethics committee of ICAR-NDRI with prior approval.

\section{Animals}

The present investigation was conducted on three sexually healthy Murrah buffalo bulls maintained at Artificial Breeding Research Centre, ICAR-National Dairy Research Institute (ICAR-NDRI), Karnal.

\section{Study area}

The farm is located on $29^{\circ} 42^{\prime} \mathrm{N}$ latitude and $72^{\circ}$ $02^{\prime} \mathrm{E}$ longitude at an altitude of $250 \mathrm{~m}$ above the mean sea level in the bed of Indo-Gangetic alluvial plain. A subtropical climate prevails in the area. There are four major seasons i.e. Winter, Summer, Rainy and Autumn in the year.

\section{Management of bulls}

Bulls were kept in the individual bull pen $\left(30^{\prime} \times 10^{\prime}\right)$ separated by solid partitions that restricted both direct physical and visual contact of bulls in adjacent pens as well as free movements within the shed. Bulls were exercised once a week, the day before semen collection in the rotary exerciser so as to maintain the sexual vigor of bulls and ensure quality semen production. Vaccination, deworming. Screening of sexually transmitted disease and other herd-health program was followed as per the farm schedule, to ensure good health.

\section{Preputial washing}

The preputial washing was done by infusing sterile, warm $\left(37^{\circ} \mathrm{C}\right)$ solutions of normal saline $(0.85 \%)$, $\mathrm{KMnO}_{4}(0.02 \%)$ and savlon $(2.0 \%)$ to first, second and third bull, respectively. The solution $(100 \mathrm{ml} / \mathrm{bull})$ was infused with the help of a sterile disposable plastic syringe $(60 \mathrm{ml})$ and white sheath of AI gun just 10 min prior to semen collection.

\section{Semen collection}

Semen was collected twice a week from each bull using sterilized artificial vagina. Two ejaculates were taken from a bull at an interval of at least $30 \mathrm{~min}$ in the morning hours. A total of 36 collections comprising of first ejaculate from each bull without preputial washing and latter ejaculates from each bull with preputial washing were taken.

\section{Semen quality assessment}

Immediately after collection, the ejaculates were brought to the laboratory and kept in water bath at $30^{\circ} \mathrm{C}$ for assessing volume, color, mass-activity, individual motility (IM), sperm concentration, non-eosinophilic, hypo-osmotic swelling test and acrosome integrity for subsequent experimentation. Semen was diluted in tris egg yolk extender to conduct studies on preservability of semen. Split semen samples were further processed for preservation at refrigerator temperature $\left(4^{\circ} \mathrm{C}\right)$ and for cryopreservation at $-196^{\circ} \mathrm{C}$ in liquid nitrogen. The microbial load and sperm quality was evaluated at different hours of storage at refrigeration temperature $(0,24$ and $48 \mathrm{~h})$ as well as before and after freezing of semen. The bacterial count $/ \mathrm{ml}$ of the sample were estimated by multiplying the dilution factor with the mean number of colonies in media plates $($ Bacterial load $/ \mathrm{ml}=$ Bacterial colonies counted on plate $\times$ dilution factor).

\section{Statistical analysis}

Data were analyzed using two-way ANOVA with interaction. The percent data on semen characteristics were subjected to arcsine transformation and a microbial count was subjected to log transformation for analysis [18].

\section{Results}

Artificial vagina (AV), glassware, semen dilutor and materials coming in contact with semen during processing are contributing to the bacterial load of the semen. Therefore, AV, glassware and extender used were subjected to assessment of bacterial load. The standard procedure of sterilization was followed to get contamination free AV. The average values of bacterial load (cfu) from washing of AV just before and after collection were 415 and 76000 , respectively. Glasswares which were subjected to contact with semen during processing and handling, were sterilized by hot air oven. The average bacterial load $(\mathrm{cfu} / \mathrm{ml})$ of sterilized and un-sterilized glassware was 112 and 42000, respectively. The average bacterial load $(\mathrm{cfu} / \mathrm{ml})$ of Tris egg yolk extender without any antibiotic treatment was $380.42(\mathrm{cfu} / \mathrm{ml})$. The average bacterial load $(\mathrm{cfu} / \mathrm{ml})$ in preputial washings by saline, savlon and $\mathrm{KMnO}_{4}$ were 3187.17, 2536.33 and 2292.83 , respectively. Semen samples were processed for the preservation of semen at $4{ }^{\circ} \mathrm{C}$ and $-196^{\circ} \mathrm{C}$ and semen quality was assessed.

\section{Preservation of semen at refrigeration temperature $\left(4^{\circ} \mathrm{C}\right)$}

Least squares means of percent individual sperm motility, non-eosinophilic count (live), hypo-osmotic swelling (HOS) reacted spermatozoa and total plate 
counts (TPCs) in semen samples before and APW at 0 , 24 and $48 \mathrm{~h}$ of preservation at refrigerated temperature are presented in Table-1. The average (\%) individual sperm motility, non-eosinophlic (live), sperm abnormalities, intact acrosome, hypo-osmotic swelling reactivity (HOST) reacted spermatozoa and microbial load estimates of semen collected before prepuce washing (BPW) of bulls and preserved at $4^{\circ} \mathrm{C}$ for 0,24 and $48 \mathrm{~h}$ are presented in Table-1.

At $0 \mathrm{~h} \mathrm{IM}$ at $4{ }^{\circ} \mathrm{C}$ was significantly higher in case of preputial washing with $\mathrm{KMnO}_{4}$ as compared to BPW group. After 24 and $48 \mathrm{~h}$ of preservation, there was no significant difference in motility between BPW and APW groups. At 0,24 and $48 \mathrm{~h}$ of preservation, the non-eosinophilic sperm values (\%) were significantly higher in APW groups except for saline treated bull. Preputial washing with $\mathrm{KMnO}_{4}$ resulted in a highest percentage of non-eosinophilic spermatozoa, followed by savlon and saline groups, respectively. After 0 and $48 \mathrm{~h}$ of preservation, there was no significant difference in the values of total sperm abnormalities between APW and BPW group. After $24 \mathrm{~h}$ of preservation, the values of total sperm abnormalities were significantly higher in BPW group than APW group. In APW group the abnormalities were lowest in $\mathrm{KMnO}_{4}$ followed by savlon and saline. However, there was no significant difference in all three solutions. After 0 and $24 \mathrm{~h}$ of preservation significant differences were observed between $\mathrm{KMnO}_{4}$ and other treatment groups, as well as between APW and BPW groups. The percent values of HOST in prepuce washing groups were higher than these without prepuce washing group. No significant difference in HOST percent between BPW and APW groups was observed. Highest HOST positive spermatozoa were observed in $\mathrm{KMnO}_{4}$ treated group followed by savlon and saline. Microbial load in semen was the lowest in case of prepuce washing with $\mathrm{KMnO}_{4}$ solution till $24 \mathrm{~h}$ of preservation. After $48 \mathrm{~h}$ of preservation, there was no significant difference in microbial load between BPW and APW groups. The bacterial load in refrigerated semen in the present study was significantly lower in APW group than BPW group.

\section{Cryopreserved semen}

Least squares means of individual sperm motility, percent non-eosinophilic counts, HOST reacted spermatozoa and TPCs in semen samples before and APW and subjected to cryopreservation are presented in Table-2. The average IM, non-eosinophlic (live); sperm abnormalities; intact acrosome; HOST reacted spermatozoa and microbial load values in pre-freeze and post-thaw semen are presented in Table- 2 .

In pre-freeze and post thawed semen the motility values were significantly higher for $\mathrm{KMnO}_{4}$ treated bull semen as compared to saline, savlon and BPW groups. In post thawed semen, the motility was not significantly higher in APW group than BPW group. In pre-freeze semen non eosinophilic sperm

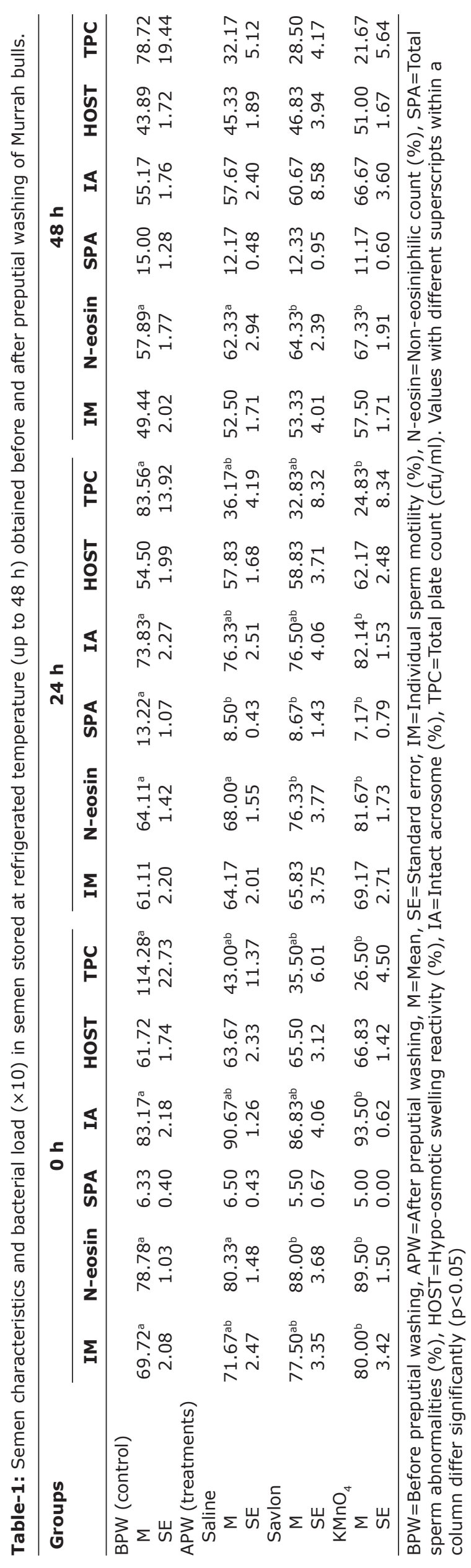

Veterinary World, EISSN: 2231-0916 
Table-2: Semen characteristics and bacterial load $(\times 10)$ in cryopreserved semen collected BPW and APW.

\begin{tabular}{|c|c|c|c|c|c|c|c|c|c|c|c|c|}
\hline \multirow[t]{2}{*}{ Groups } & \multicolumn{6}{|c|}{ Pre freeze semen } & \multicolumn{6}{|c|}{ Post thaw semen } \\
\hline & IM & N-eosin & SPA & IA & HOST & TPC & IM & N-eosin & SPA & IA & HOST & TPC \\
\hline \multicolumn{13}{|c|}{ BPW (control) } \\
\hline M & $69.72^{\mathrm{a}}$ & $78.78^{a}$ & 6.33 & $83.17^{a}$ & 61.72 & $114.28^{a}$ & 48.33 & 61.50 & 15.17 & $62.56^{\mathrm{a}}$ & $37.89^{a}$ & 65.61 \\
\hline SE & 2.08 & 1.03 & 0.40 & 2.18 & 1.74 & 22.73 & 1.57 & 1.58 & 1.09 & 1.26 & 1.58 & 16.04 \\
\hline \multicolumn{13}{|c|}{ APW (treatments) } \\
\hline \multicolumn{13}{|c|}{ Saline } \\
\hline M & $71.67^{a b}$ & $80.33^{a}$ & 6.50 & $90.67^{\mathrm{ab}}$ & 63.67 & $43.00^{\mathrm{ab}}$ & 52.50 & 64.17 & 13.83 & $64.33^{\mathrm{ab}}$ & $40.33^{a b}$ & 23.17 \\
\hline SE & 2.47 & 1.48 & 0.43 & 1.26 & 2.33 & 11.37 & 2.14 & 2.01 & 2.20 & 2.03 & 3.88 & 4.81 \\
\hline \multicolumn{13}{|l|}{ Savlon } \\
\hline M & $77.50^{\mathrm{ab}}$ & $88.00^{\mathrm{b}}$ & 5.50 & $86.83^{a b}$ & 65.50 & $35.50^{\mathrm{ab}}$ & 54.17 & 66.33 & 12.67 & $69.00^{\mathrm{ab}}$ & $44.17^{\mathrm{ab}}$ & 21.17 \\
\hline SE & 3.35 & 3.68 & 0.67 & 4.06 & 3.12 & 6.01 & 5.07 & 5.09 & 1.45 & 4.09 & 4.47 & 4.53 \\
\hline \multicolumn{13}{|l|}{$\mathrm{KMnO}_{4}$} \\
\hline$M^{4}$ & $80.00^{\mathrm{b}}$ & $89.50^{\mathrm{b}}$ & 5.00 & $93.50^{\mathrm{b}}$ & 66.83 & $26.50^{\mathrm{b}}$ & 55.00 & 67.67 & 11.83 & $73.67^{b}$ & $50.33^{b}$ & 16.67 \\
\hline SE & 3.42 & 1.50 & 0.00 & 0.62 & 1.42 & 4.50 & 2.89 & 2.50 & 2.15 & 2.40 & 4.77 & 5.19 \\
\hline
\end{tabular}

$\mathrm{BPW}=$ Before preputial washing, $\mathrm{APW}=$ After preputial washing, $\mathrm{M}=$ Mean, $\mathrm{SE}=$ Standard error, $\mathrm{IM}=$ Individual sperm motility (\%), N-eosin=Non-eosiniphilic count (\%), SPA=Total sperm abnormalities (\%), HOST=Hypo-osmotic swelling reactivity (\%), IA=Intact acrosome (\%), TPC=Total plate count (cfu/ml). Values with different superscripts within a column differ significantly

values were significantly higher in $\mathrm{KMnO}_{4}$ and savlon treated groups. Whereas, in post thawed semen there was no significant difference among different treatments and solutions used. Preputial washing with $\mathrm{KMnO}_{4}$ resulted in lowest sperm abnormalities. In pre-freeze semen no significant difference in total sperm abnormalities was observed between BPW and APW group. In pre-freeze and post-thaw semen intact acrosomes were significantly higher in $\mathrm{KMnO}_{4}$ as compared to BPW, savlon and saline treated bull semen samples. This may be due reduction of toxic metabolites of bacteria and thus plasma membrane integrity remains intact in $\mathrm{KMnO}_{4}$ treated group. Post thawed semen HOST values were significantly higher in $\mathrm{KMnO}_{4}$ treated semen samples. The analysis of variance showed significant effect $(p<0.01)$ of stage, solution and stage-solution interaction on HOST. The HOS response and acrosome status of sperms in APW group were significantly higher than BPW group. Prepuce washing with $\mathrm{KMnO}_{4}$ treatment had the highest efficacy in terms of sustaining membrane integrity. In pre-freeze stage, bacterial load was significantly less in semen samples APWs with $\mathrm{KMnO}_{4}$ solution than the samples without preputial washing. In post thawed semen there was no significant difference in microbial load among different treatments.

\section{Discussion}

The findings of bacterial load in refrigerated semen after preputial wash in the present study were similar to the results of various researchers in crossbred bull [15] and in camel [19]. Microbial contamination in semen may interfere with the sperm function and fertilization potential due to the formation of reactive oxygen species by macrophages and polymorphonuclear granulocytes and decrease in motility due to adherence of microbes with spermatozoa. Microbes may have a direct effect on acrosome through toxin production [10]. Bacteria appear to exert their spermicidal effect directly upon the sperm cell. Bacteria compete with cells (spermatozoa) for nutrients and oxygen necessary for growth and normal functioning [20]. The preputial cavity is the main source of contamination in semen. Most of the bacteria can be declared as a commensal, but there are also potentially pathogenic germs that can contaminate the collected semen [21]. In semen Staphylococcus spp., Escherichia coli, Streptococcus spp. are the most common organisms [22], which may have an influence on the motility and viability of bovine semen. Preputial cavity is the main source of contamination in semen. Therefore, preputial washing with antiseptic solution helps in reduction of microbial load, which resulted in better quality semen by inactivating or destroying microbes in semen.

The results of non-eosinophilic sperm values were in accordance with those of findings earlier reported by Bindra et al. [16]. This result may be due to minimum bacterial contamination and improvement in hygienic quality of semen before freezing. The HOST and acrosome status of sperms in semen are in conformity with those of Monga and Roberts [23]. Similar to our results Ortega-Ferrusola et al. [24] concluded that the microbial flora of the ejaculate may be responsible for damage of spermatozoa during cryopreservation. Higher sperm abnormalities in BPW group might be due to spermicidal and deleterious effect of bacteria. Reports depict that sometime morphological abnormalities leads to changes in the acrosomal integrity of spermatozoa [25]. The sperm abnormalities in semen were the lowest in $\mathrm{KMnO}_{4}$ treated bull semen. It may be due to the better efficacy of the solution against various organisms. The microbial load among post thawed semen in different treatments showed findings akin with those of Bhakat and Raina [17]. Initial quality of semen can be improved hygienically by adopting preputial washing before semen collection.

The better efficiency of $\mathrm{KMnO}_{4}$ for preputial washing as compared to savlon and saline solution 
may be due to effective control of various microorganisms (bacteria, fungi, virus and algae), on the other side savlon acts as bacteriostat and effectivity of saline is further less. $\mathrm{KMnO}_{4}$ also helps in reduction of toxins produced by microorganisms, which further helps in reduction of oxidative stress on spermatozoa, thus showing in the improvement of semen quality. The broad spectrum role of $\mathrm{KMnO}_{4}$ may help to control and inactivate microbes and shows more effective as compared to savlon and normal saline. It may be due to minimum bacterial contamination and improvement in hygienic quality of semen before freezing.

The process of freezing has great impact on motility, sperm abnormalities, normal acrosomes and intact plasma membranes and in similar fashion the quality is getting affected during preservation of semen at refrigeration temperature, but severity may be less, as there is increase in large numbers of dead and abnormal sperms after cryopreservation as compared to preservation at refrigerated temperature. Dead spermatozoa normally release reactive oxygen species (ROS) and certain other toxic substances. ROS acts through lipid peroxidation of carbon chain of unsaturated fatty acid to form highly cytotoxic lipid hydroperoxides, which decompose to form end product malondialdehyde, which is highly toxic and is responsible for DNA and protein damage finally leading to cell death as well as damage the fertilization potential of other healthy sperms. During cryopreservation and thawing process there was considerable damage to the motility apparatus, plasma membrane and acrosomal cap which may be due to leakage of enzymes responsible for sperm motility, weaker plasma membrane of spermatozoa, dehydration, ice-crystal formation during freezing as well swelling and corrugation of the anterior part of the acrosome. There was considerable irreversible loss after cryopreservation, which cannot be avoided.

\section{Conclusion}

Overview of the results suggested that prepuce washing with $\mathrm{KMnO}_{4}$ solution would facilitate quality semen production in terms of reduced microbial load, sperm abnormalities and higher sperm motility, livability, membrane integrity, acrosome intactness in the semen stored at refrigerator temperature $\left(4^{\circ} \mathrm{C}\right)$ and in liquid nitrogen $\left(-196^{\circ} \mathrm{C}\right)$ due to broad spectrum effect. Use of a higher amount of $\mathrm{KMnO}_{4}$ for preputial washing is not advisable as it may act as an irritant, which may affect the quality semen production. Preputial washing with normal saline and savlon is also good, but best results can be obtained using $\mathrm{KMnO}_{4}$ for prepuce washing.

\section{Authors' Contributions}

GS did bench work under the supervision of VSR, AKG and TKM. MB, RB and MA helped in the technical input, bench work, statistical analysis and in making the final manuscript of the research. All authors read and approved the final manuscript.

\section{Acknowledgments}

The authors are thankful to Director, NDRI for providing the necessary funds to carry out the present work.

\section{Competing Interests}

The authors declare that they have no competing interests.

\section{References}

1. Diemer, T., Weidner, W., Michelmann, H.W., Schiefer, H.G., Rovan, E. and Mayer, F. (1996) Influence of Escherichia coli on motility parameters of human spermatozoa in vitro. Int. J. Androl., 19(5): 271-277.

2. Griveau, J.F., Domount, E., Renard, P., Challegani, J.P. and Lelannou, D. (1995) Reactive oxygen species lipid peroxidationand enzymatic defense system in human spermatozoa. J. Reprod. Fertil., 103: 17-26.

3. Maroto Martin, L.O., Munoz, E.C., De Cupere, F., Van Driessche, E., Echemenda-Blanco, D., Rodriguez, J.M. and Beeckmans, S. (2010) Bacterial contamination of boar semen affects the litter size. Anim. Reprod. Sci., 120(1-4): 95-104.

4. Fatnassi, M., Padalino, B., Monaco, D., Khorchani, T., Lacalandra, G.M. and Ham-madi, M. (2014) Evaluation of sexual behavior of housed male camels (Camelus dromedarius) through female parades: Correlation with climatic parameters. Trop. Anim. Health Prod., 46: 313-321.

5. Patel, H.V., Patel, R.K. and Chauhan, J.B. (2011) Biochemical properties of microbial load in frozen semen of cattle. Wayamba J. Anim. Sci., 3, Article No. 1308233242.

6. Bureau of Indian Standard (BIS). (2012), Annual Report, 2011-2012.Available from: http://www.bis.org.in/org/ ANNUALREPORT1112. pdf. Accessed on 15-05-2015.

7. Najee, H.B., Al-Shawii, A.M and Abd-Al Rahman, L.Y. (2012), Bacterial contamination of imported bulls frozen semen. Al-Anbar J. Vet. Sci., 5(1), ISSN: 1999-6527.

8. Yaniz, J.L., Marco-Aguado, M.A., Mateos, J.A. and Santolaria, P. (2010) Bacterial contamination of ram semen, antibiotic sensitivities, and effects on sperm quality during storage at $15^{\circ}$ C. Anim. Reprod. Sci., 1-2: 142-149.

9. Mozo-Martín, R., Dahmani, Y., Larraz, C. and Ubeda J.L. (2010) Main Bacterial species isolated from commercial seminal doses and antibiotic activity. Magapor, 22: 57-61.

10. Morrell, J.M. (2006) Update on semen technologies for animal breeding. Reprod. Domest. Anim., 41: 63-67.

11. Patel, D.Y. and Patel, R.K. (2012) Estimation of biochemical activities of microbial load isolated from the frozen semen of HF and HF crossbred cattle bulls. Curr Trend Biotech. Pharm., 6(3): 328-339.

12. Noakes, E.D., Parkinson, T.J. and England, G.C. (2009) Trichomoniasis. In: Veterinary Reproduction and Obstetrics. $9^{\text {th }}$ ed. Saunders, Philadelphia. p495-499.

13. Azawi, O.I. and Ismaeel, M.A. (2012) Effects of seasons on some semen parameters and bacterial contamination of Awassi ram semen. Reprod. Domest. Anim., 47: 403-406.

14. Jasial, S., Katoch, R.C., Chachara, D., Mahajan, A. (2000) Evaluation of bacterial load in fresh ejaculates of bovine and buffalo bull semen in Himachal Pradesh. Indian J. Anim. Sci., 70: 465-467.

15. Rathnamma, D., Rao, M.S., Ramanatha, K.R., Raghavan, R. (1997) Assessment of bacterial load in semen of Holstein Friesian bulls. Curr. Res. Univ. Agric. Sci. Bangalore, 26(11): 205-207.

16. Bindra, D.S., Pangawkar, G.R., Matharoo, J.S. and Singh, M. (1994) Effect of preputial washing on semen quality of buffalo bulls. Indian J. Anim. Reprod., 15: 75-76.

17. Bhakat, C. and Raina, V.S. (2001) Effect of preputial washing and antibiotic treatment on bacterial load and 
preservability of frozen bovine semen. Indian J. Anim. Sci., 71: 1127-1130.

18. Snedecor, G.W. and Cochran, W.G. (1994) Statistical Methods. $6^{\text {th }}$ ed. Oxford and IBH Publ. Co., New Delhi.

19. Ghoneima, I.M., Waheeda, M.M., Al-hofofib, A.N., Fayezc, M.M., Al-Eknaha, M.M., Al-Busadahd, K.A. and Al-humame, N.A. (2014) Evaluation of the microbial quality of fresh ejaculates of camel (Camelus dromedarius) semen. Anim. Reprod. Sci., 149: 218-223.

20. Rodeheaver, G.T. (1997) Wound cleansing, wound irrigation, wound disinfection. In: Krasner, D., Kane, D., Wayne, P.A., editors. Chronic Wound Care: A Clinical Source Book for Healthcare Professionals. $2^{\text {nd }}$ ed. Health Management Publications Inc., p97-108.

21. Aurich, C. and Spergser, J. (2007) Influence of bacteria and gentamicin on cooled-stored stallion spermatozoa.
Theriogenology, 67(5): 912-918.

22. Corona, A. and Cherchi, R. (2009) Microbial quality of equine frozen semen. Anim. Reprod. Sci., 115: 103-109.

23. Monga, M. and Roberts, J.A. (1994), Sperm agglutination by bacteria: Receptor-specific interactions. J. Androl., 15: 151-158.

24. Ortega-Ferrusola, C., Gonzalez-Fernández, L., Muriel, A., Macías-García, B., Rodríguez-Martínez, H., Tapia, J.A., Alonso, J.M. and Pẽna, F.J. (2009) Does the microbial flora in the ejaculate affect the freezeability of stallionsperm? Reprod. Domest. Anim., 44: 518-522.

25. Akhter, S., Ansari, M., Andrabi, S., Ullah, N. and Qayyum, M. (2008) Effect of antibiotics in extender on bacterial and spermatozoal quality of cooled buffalo (Bubalus bubalis) bull semen. Reprod. Domest. Anim., 43: 272-278.

$* * * * * * * *$ 